
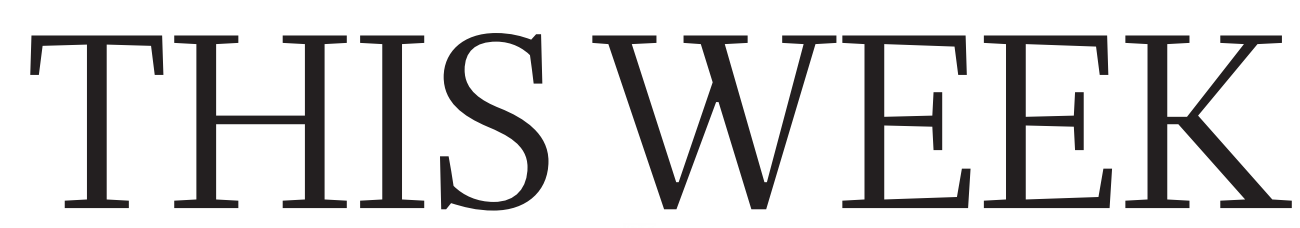

EDITORIALS

ENVIRONMENT Agency head is wrong about grantees conflicts of interest $\mathbf{p . 1 4 2}$
PUBLIC HEALTH Put African

researchers in charge of

local data $\mathbf{p} \mathbf{1 4 3}$
REPRODUCIBILITY First prize for publishing negative results launched $\mathbf{p} \mathbf{1 4 9}$

\title{
Skin with insights
}

\section{A feat in stem-cell therapy highlights what can be achieved when basic and clinical research combine to advance biological understanding and medical treatment.}

$\mathrm{S}$ omewhere in Germany's Ruhr valley, a nine-year-old boy is doing what children do: playing football, joking around with friends and going to school. Two years ago, he was confined to a hospital bed, dying of a rare and cruel genetic skin disease. In a landmark paper online in Nature this week, scientists and clinicians present the details of his astonishing recovery (T. Hirsch et al. Nature http://dx.doi. org/10.1038/nature24487; 2017).

The boy had junctional epidermolysis bullosa, or JEB. He, like other people with the disease, carried a mutation in a gene that controls the integrity of the skin. Doctors could only try to ease his suffering as some $80 \%$ of his skin simply fell away.

A team of Italian researchers came to his aid by combining stem-cell techniques with gene therapy. As a young scientist at Harvard Medical School in Boston, Massachusetts, in the 1980s, Michele De Luca - the lead author of the new study - watched pioneers in skin regeneration learn to grow small sheets of skin from cells taken from burns patients, and to use them in grafts. He extended the work in Italy, applying new genetic and stem-cell technologies. He developed ways to generate stem cells from human skin, replace disease-causing genes in them and grow sheets of healthy skin on scaffolds in the lab.

He chose JEB for his first clinical trial, which he registered with the Italian Medicines Agency in 2002. Four years later, he reported his first success, in which he created healthy skin patches from biopsies to replace small areas of sloughed-off skin on the legs of a patient with a form of JEB (F. Mavilio et al. Nature Med. 12, 1397-1402; 2006). New European Commission regulations introduced in 2007 required him to pause the project while he created facilities adhering to 'good manufac-turing practices' (GMPs) and a spin-off company to meet the demands for strengthened oversight of cell-based therapies.

Having a company refocused his team's attention on a different type of stem-cell therapy, one likely to yield a product for the market faster. Holoclar, a treatment that replaces the eye's cornea in a form of blindness, became the world's first commercial stem-cell therapy in 2015.

A few months later, at the University of Modena, De Luca got a call out of the blue from doctors in Germany who were trying to treat the little boy. Because the therapy had been in a clinical trial, albeit one on hold at the time, and because De Luca could provide GMP services, German regulatory authorities quickly approved the one-off compassionate use of the JEB therapy. Surgeons in Germany sent a skin biopsy to Modena, and two major skin transplants followed. Six months after the initial biopsy, the boy returned to school. During the many months since, he has not had so much as a blister, and loves to show off his 'new skin'.

This major clinical development was based on decades of basic research. The clinical data gathered during 21 months of follow-up after the boy's treatment have also led to major insights into human skin biology, as discussed in an accompanying News \& Views (M. Aragona and C. Blanpain Nature http://dx.doi.org/10.1038/ nature 24753 ; 2017). For example, normal regeneration of the epidermis

is directed by only a few stem-cell clones that can self-renew.

By their nature, highly personalized treatments using gene therapies and products derived from an individual's stem cells are likely to be applicable to only a subset of patients. Although the report presents the treatment of one patient, it is a classic case of researchers standing on the shoulders of others. This project, for example, relied on long-term follow-up of a patient treated in 2006, as well as parallel studies that

"This major clinical development was based on decades of basic research." tion between doctors, scientists, regulators and technicians at many levels - a particularly important aspect in areas such as stem-cell biology. It requires the highest standards of scientific and ethical diligence. Similar treatments are starting to be rolled out in other labs for other diseases. Nature is glad to celebrate and support such an enterprise.

\section{Study fatigue}

\section{Researchers should recognize communities that feel over-researched and under-rewarded.}

I n southern Beirut, a temporary shelter has become a permanent home. The Shatila refugee camp was established to house displaced Palestinians in 1949 and now has thousands of families within its walls. Residents have learnt to contend with overcrowding, pollution - and a steady stream of well-funded foreign researchers who come to study them.

Drawn by its unusual story and convenient position close to the airport, researchers flock to Shatila to track the effects of prolonged refugee status and cultural isolation on the community. Well-meaning researchers are so common in Shatila that locals have learnt how to spot them.

Before she became a social anthropologist at King's College London, Mayssoun Sukarieh did voluntary work in Shatila. Residents who saw her reach for her notebook would ask if she was a social researcher: "They come for a tiny bit, and then they leave," the locals explained.

Sukarieh realized that scholars' repeated visits were affecting the community. Academics were among the few contacts that people in Shatila had with the wider world. Again and again, the outsiders would 